\title{
ANALISIS STRUKTUR RANTAI PASOK KONTRUKSI PADA PEKERJAAN JEMBATAN
}

\author{
Febiana Maulani ${ }^{1}$, Akhmad Suraji $^{2}$ dan Bambang Istijono ${ }^{3}$
}

\begin{abstract}
ABSTRAK
Rantai Pasok adalah suatu item kegiatan atau jaringan kerjasama pengadaan barang atau jasa yang berkerja sama dan saling terkait satu sama lain untuk membuat dan menyalurkan barang atau jasa. Sedangkan, struktur rantai pasok adalah susunan suatu item kegiatan atau jaringan kerjasama pengadaan barang atau jasa yang berkerja sama dan saling terkait satu sama lain untuk membuat dan menyalurkan barang atau jasa. maka, pada suatu proyek kontruksi suatu sistem rantai pasok sangat mempengaruhi kelancaran suatu proyek. Baiknya suatu sistem rantai pasok kontruksi akan meningkatkan kinerja dari suatu kontraktor pada suatu proyek. Tujuan dari penelitian ini adalah untuk mengetahui kinerja suatu kontraktor pada suatu proyek kontruksi jembatan dengan mengkaji melalui struktur rantai pasok yang digunakan. Hasil dari penelitian yang dilakukan pada kontraktor, subkontraktor dan supplier pada konstruksi jembatan dengan beberapa aspek penentu seperti hubungan dengan subkontraktor dan supplier seperti, jenis pengadaan, jenis kontrak, system pembayaran, dan interaksi antara dua perusahaan menunjjukn adanya keterkaitan antara hubungan kerja sama yang baik terhadap keefektifan pelaksanaan pekerjaan konstruksi.
\end{abstract}

Kata kunci : rantai pasok, supplier, subkontraktor, Tier, konstruksi jembatan.

\section{PENDAHULUAN}

\subsection{Latar Belakang}

Sehubungan dewasa ini terjadi peningkatan harapan customer terhadap hasil produk konstruksi yang dihasilkan para penyedia jasa konstruksi menyebabkan persaingan global antar perusahaan penyedia jasa konstruksi semakin ketat. Oleh karena itu, hal ini memaksa para penyedia jasa konstruksi untuk berupaya lebih keras lagi dalam meningkatkan kinerja operasi perusahaan agar sesuai dengan keinginan pengguna jasa atau customer. Selain itu, jumlah kontraktor yang semakin bertambah dan berbanding terbalik dengan jumlah proyek yang turut menyebabkan kondisi yang tidak berimbang antara penyedia jasa dengan pengguna jasa. Kondisi ini dapat memicu persaingan yang sangat ketat diantara para penyedia jasa konstruksi dalam mempertahankan kelangsungan usaha. Disisi lain kondisi tersebut menjadikan pengguna jasa memiliki posisi bargaining yang kuat dalam menentukan penyedia jasa yang tepat untuk mengakomodir kebutuhan yang diperlukan.

Maka salah satu cara yang dapat digunakan dalam menghadapi tantangan tersebut adalah melakukan kerja sama yang saling menguntungkan antar pihak-pihak yang terlibat demi mencapai tujuan bersama. Penerapan metode rantai pasok diyakini oleh beberapa peneliti bidang rantai pasok

\footnotetext{
${ }^{1}$ Mahasiswa Jurusan Teknik Sipil Fakultas Teknik Universitas Andalas, febiana.maulani@gmail.com

${ }^{2}$ Staf Pengajar Jurusan Teknik Sipil Fakultas Teknik Universitas Andalas, akhmad.suraji@gmail.com

${ }^{3}$ Staf Pengajar Jurusan Teknik Sipil Fakultas Teknik Universitas Andalas, bistijono1452@yahoo.co.id
} 
dapat menjadi salah satu solusi dari persoalan-persoalan yang terkait dengan penghantaran produk dari pemasok ke pengguna akhir (end user).

Menurut Suraji dan Dirohanta (2012) Proyek gedung baik untuk hunian (residential buildings) maupun bukan hunian (non-residential buildings) merupakan salah satu sektor konstruksi di Indonesia. Proyek gedung banyak diselenggarakan oleh pihak swasta khususnya di kota-kota besar untuk fungsi properti maupun pemerintah untuk fungsi perkantoran. Rantai pasok konstruksi di sektor gedung dapat melibatkan banyak pihak (Tier) mulai dari konsultan, perencana, perancang, kontraktor, subkontraktor, pemasok barang/ material, pemasok peralatan, distributor dan pabrikan. Masing-masing pihak dalam suatu Tier dapat berjumlah banyak karena proyek gedung terdiri dari banyak komponen/ elemen pekerjaan yang memerlukan banyak pihak pemasok. Rantai pasok konstruksi di sektor gedung boleh jadi berbeda dengan sektor lainnya. Seperti pada Tugas Akhir ini akan dibahas rantai pasok pada kontruksi jembatan yang akan memiliki alur pemasokan barang, material, dan jasa yang berbeda sesuai kebutuhan dari proyek kontruksi tersebut. Berdasarkan uraian diatas maka perlu dilakukan penelitian tentang jaringan sistem rantai pasok material dan peralatan pada proyek konstruksi dan pihak-pihak yang terlibat dalam pengelolan rantai pasok pengadaan material dan peralatan proyek konstruksi jembatan.

\subsection{Tujuan dan Manfaat}

Tujuan dari penelitian ini adalah mengidentifikasi dan menganalisa struktur rantai pasok peralatan dan material pada proyek konstruksi jembatan. Manfaat penelitian ini adalah untuk mengetahui faktor - faktor penentu dari peningkatan efisiensi waktu, biaya, mutu dan penyelenggaraan proyek konstruksi dan terciptanya integrasi pada proyek tersebut.

\subsection{Batasan Masalah}

Ruang lingkup penelitian ini dibatasi pada proyek konstruksi jembatan Kelok Sembilan tahun 2011 dan 2012 yang dibiayai dari Kementrian Pekerjaan Umum. Pada penelitian ini lebih difokuskan kepda faktor penentu kelancaran proyek kontruksi jembatan berdasarkan rantai pasok.

\subsection{Rantai Pasok}

Ada beberapa definisi dari rantai pasok yaitu pertama dari Russel dan Taylor (2000:373) yang mendefinisikan rantai pasok terbentuk dari sebuah perhubungan organisasi, sumber dan proses yang menciptakan serta mengirimkan produk dan jasa kepada pemakai akhir. Sebuah rantai pasok mencakup semua fasilitas, fungsi dan aktifitas yang terlibat dalam produksi dan pengiriman sebuah produk atau jasa dari para supplier ke konsumen. Sedangkan menurut Chopra and Meindl (2007: 20), rantai pasok memiliki sifat yang dinamis namun melibatkan tiga aliran yang konstan, yaitu aliran informasi, produk dan uang. Disamping itu, Chopra and Meindl juga menjelaskan bahwa tujuan utama dari setiap rantai pasok adalah untuk memenuhi kebutuhan konsumen dan menghasilkan keuntungan. Sementara itu, Ling Li (2007 : 3) memaparkan bahwa rantai pasok lebih menekankan pada semua aktivitas dalam memenuhi kebutuhan konsumen yang di dalamnya terdapat aliran dan transformasi barang mulai dari bahan baku sampai ke konsumen akhir dan disertai dengan aliran informasi dan uang.

Selanjutnya Lambert et al (2004;18-26) menjelaskan rantai pasok terdiri dari rangkaian pihak-pihak yang dapat tersebar secara geografis. Pihak-pihak tersebut adalah penyedia bahan baku, manufaktur, pusat distribusi, pengecer atau pedagang kecil serta transportasi yang membawa bahan baku, intermediate product atau produk jadi ke pihak-pihak yang membutuhkan. Maka dari definisi definisi di atas dapat disimpulkan rantai pasok itu adalah suatu item kegiatan atau jaringan kerjasama pengadaan barang atau jasa yang berkerja sama dan saling terkait satu sama lain untuk membuat dan menyalurkan barang atau jasa.

\section{I JURNAL REKAYASA SIPIL}




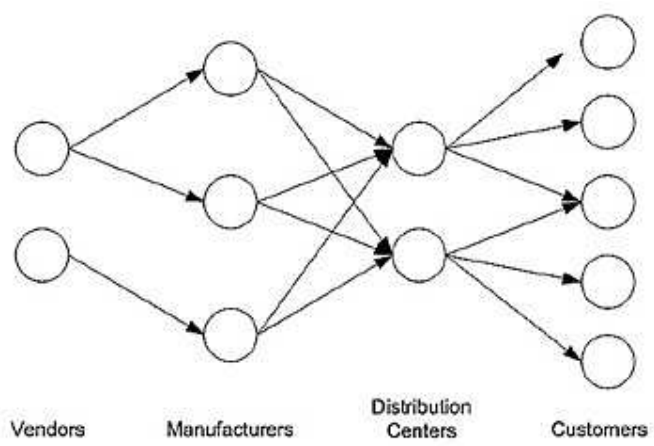

Gambar 1.1 RantaiPasok

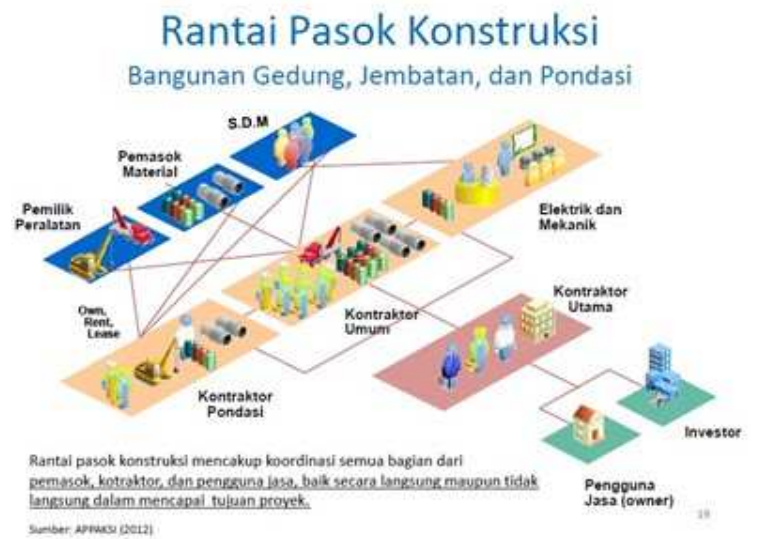

Gambar 1.2 RantaiPasokKonstruksiBangunanGedung, Jembatan, danPondasi

\subsection{Metodologi}

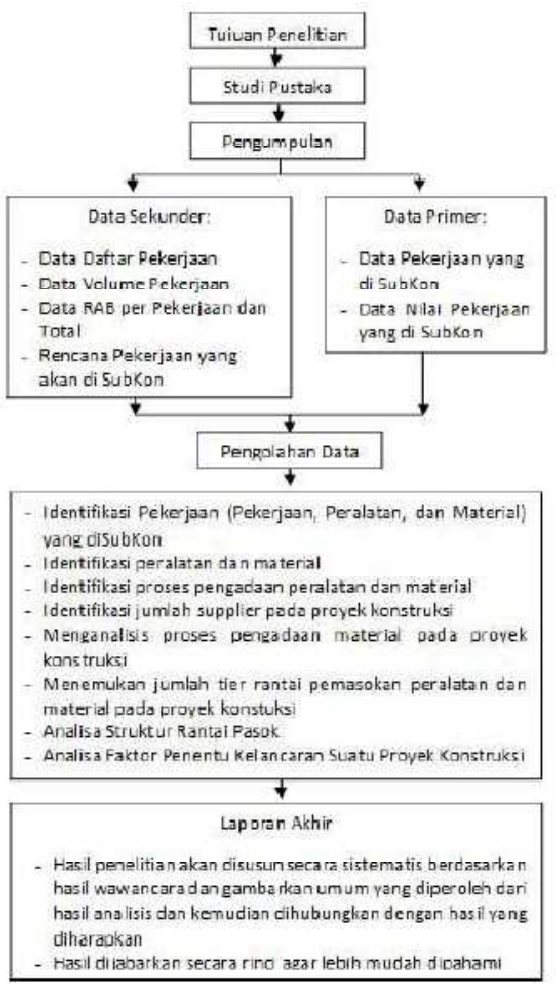

Gambar 1.3 Alur Kegiatan Penelitian 


\section{STRUKTUR RANTAI PASOK}

\subsection{Analisa Struktur Rantai Pasok}

Pengertian dari struktur rantai pasok adalah susunan suatu item kegiatan atau jaringan kerjasama pengadaan barang atau jasa yang berkerja sama dan saling terkait satu sama lain untuk membuat dan menyalurkan barang atau jasa. Sedangkan, Menurut Harland (1996) struktur rantai pasok adalah susunan pengelolaan suatu jaringan bisnis yang saling berhubungan yang terlibat dalam penyediaan akhir paket-paket produk dan layanan yang diperlukan oleh konsumen akhir.

Selain itu, ada tiga aspek struktural utama dari rantai pasok, yaitu :

1. Struktur jaringan perusahaan yang merupakan anggota dari rantai pasok

2. Struktural dimensi dari jaringan

3. Perbedaan tipe dari hubungan proses yang melewati rantai pasok

Maka tahap perancangan jaringan rantai pasok adalah

1. Mengidentifikasi anggota. Yaitu mengindentifikasi pelaku dari suatu kerja sama (rantai) pada sebuah proyek konstruksi seperti kontraktor utama, subkon, supplier, vendor, produsen, dan lain-lain yang berkontribusi dalam alur pasok barang dan jasa pada suatu proyek konstruksi.

2. Stuktural dimensi jaringan. Struktural dimensi terdiri dari tiga jenis dimensi, yaitu :

a. Struktur Horizontal yaitu jumlah Tier (urutan) yang melewati rantai pasok

b. Struktur vertikal yaitu jumlah supplier atau custumer yang digambarkan didalam masing - masing deretan.

c. Posisi horizontal yaitu posisi perusahaan berada pada sumber/custuner akhir atau pada beberapa tempat diantara titik akhir rantai pasok.

3. Tipe dari mata rantai bisnis yaitu

a. mata rantaiproses pengelolaan

b. mata rantai proses monitor

c. mata rantai tidak mengelola proses

d. mata rantai bukan anggota proses

4. Pemetaan rantai pasok.

Pada peta rantai pasok jembatan kelok 9 tahun 2011 dan 2012 terdapat 4 pekerjaan yang dilakukan langsung oleh kontraktor dan 2 pekerjaan yang di subkontraktorkan. Pekerjaan yang menggunakan subkontraktor antara lain adalah pekerjaan aspal dan pekerjaan minor. Sedangkan yang dikerjakan langsung oleh kontraktor yaitu pekerjaan drainase, pekerjaan tanah, pekerjaan perkerasan beton cemen, dan pekerjaan struktur. Sedangkan untuk peralatan yang digunakan pada proyek jembatan merupakan peralatan sewaan.

\subsection{Analisa Hubungan Interaksi Kontraktor}

Pada rantai pasok dari dua pekerjaan jembatan pada proyek kelok 9 terlihat bahwa pembagian item pekerjaan yang dilakukan hampir sama. Hal yang membedakan pekerjaan jembatan kelok 9 tahun 2011 dan 2012 adalah penambahan beberapa item pekerjaan yang dilakukan pada pekerjaan jembatan tahun 2012 seiring dengan pertambahan nilai kontrak pada pengerjaan jembatantahun 2012. Pada analisis rantai pasok ini, akan ditinjau dari sistem pengadaan, sistem pembayaran, kontrak kerja, dan interaksi dengan kontraktor utama. Maka dari itu, dilakukan wawancara langsung dengan beberapa supplier dan subkontraktor yang berhubungan langsung saat proyek kelok 9 berjalan.

Hasil dari analisa hubungan interaksi kontraktor tersebut ditunjukkan dalam Tabel 2.1: 

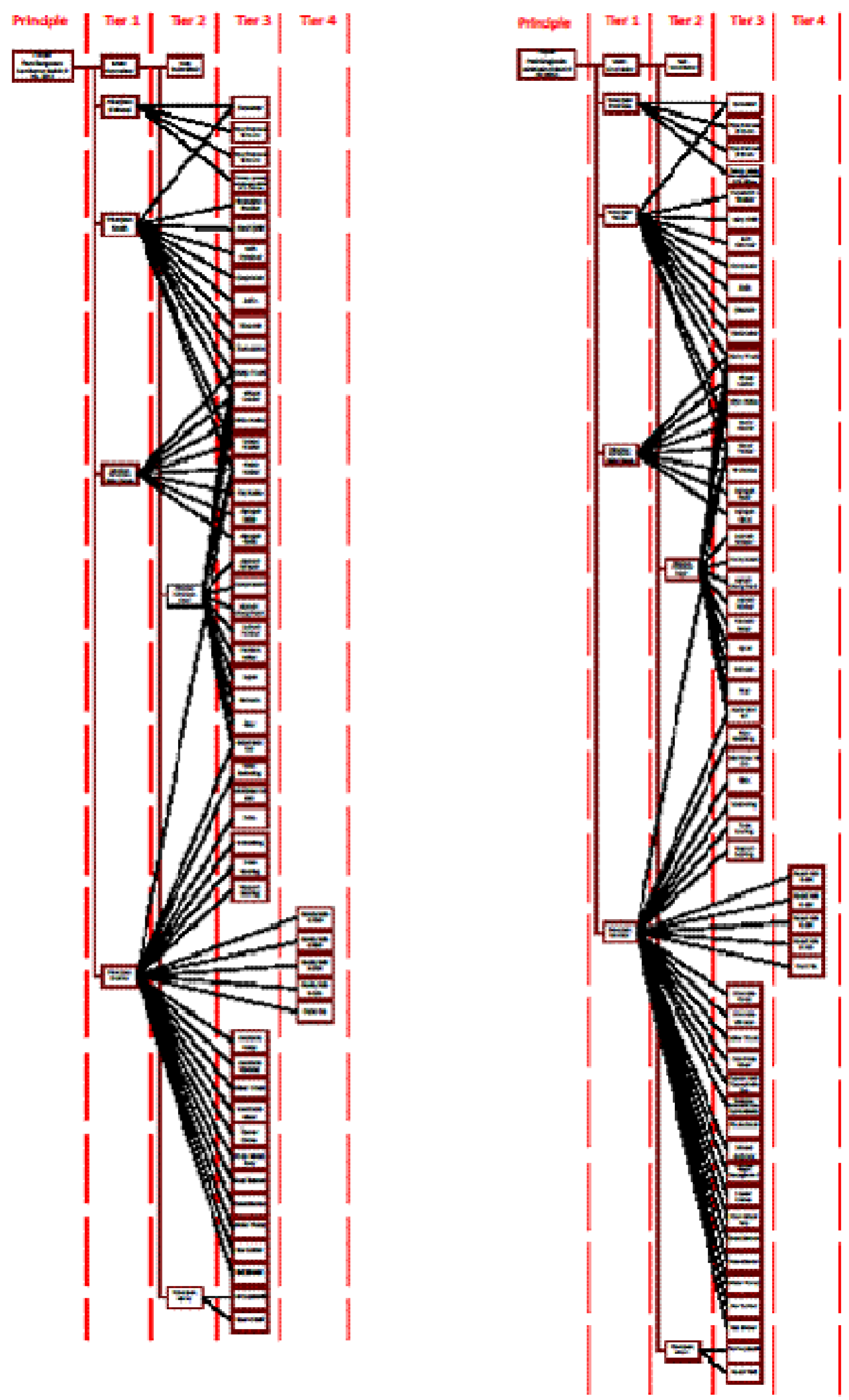

VOLUME 10 NO. 2, OKTOBER 2014 | 5 
Tabel 2.1. Analisa Hubungan Interaksi Dengan Kontraktor Utama

\begin{tabular}{|c|c|c|c|c|c|c|}
\hline Pemasok & $\begin{array}{l}\text { Kontrakt } \\
\text { or Utama }\end{array}$ & $\begin{array}{c}\text { Pekerjaan/ } \\
\text { Barang yang } \\
\text { dipasok }\end{array}$ & $\begin{array}{c}\text { Sistem } \\
\text { Pengadaan }\end{array}$ & $\begin{array}{c}\text { Sistem } \\
\text { Pembayaran }\end{array}$ & $\begin{array}{c}\text { Kontrak } \\
\text { kerja }\end{array}$ & Intetraksi \\
\hline $\begin{array}{l}\text { PT. Statika } \\
\text { Mitrasarana }\end{array}$ & $\begin{array}{l}\text { PT. Adhi } \\
\text { Karya }\end{array}$ & $\begin{array}{l}\text { Ready Mix } \\
\text { Aspal }\end{array}$ & $\begin{array}{l}\text { Penunjukan } \\
\text { Langsung }\end{array}$ & $\begin{array}{l}\text { Unit Price } \\
\text { dengan } \\
\text { Uang Muka }\end{array}$ & $\begin{array}{l}\text { Unit } \\
\text { Price }\end{array}$ & $\begin{array}{l}\text { Kerja sama telah } \\
\text { dilakukan sejak } \\
\text { lama. Masalah } \\
\text { yang terjadi saat } \\
\text { kerja sama } \\
\text { adalah } \\
\text { keterlambatan } \\
\text { pembayaran dari } \\
\text { kontraktor utama }\end{array}$ \\
\hline $\begin{array}{l}\text { Toko } \\
\text { Sumber } \\
\text { Baru }\end{array}$ & $\begin{array}{l}\text { PT. Adhi } \\
\text { Karya }\end{array}$ & $\begin{array}{l}\text { Besi } \\
\text { Besi IWF } \\
\text { H Beam } \\
\text { Kawat Beton } \\
\text { Triplek }\end{array}$ & Tidak ada & SCF & $\begin{array}{l}\text { Tidak } \\
\text { ada }\end{array}$ & $\begin{array}{l}\text { Pembayaran } \\
\text { dilakukan } \\
\text { dengan jaminan } \\
\text { bank, dan } \\
\text { pembayaran } \\
\text { dilakukan } \\
\text { dengan cara } \\
\text { kredit selama } 2 \\
\text { bulan. Hanya } \\
\text { menjual barang } \\
\text { ready stock. } \\
\text { Telah } \\
\text { mempunyai } \\
\text { hubungan kerja } \\
\text { sama yang baik } \\
\text { sejak lama. } \\
\text { Masalah yang } \\
\text { terjadi yaitu } \\
\text { keterlambatan } \\
\text { pembayaran }\end{array}$ \\
\hline Toko Rado & $\begin{array}{l}\text { PT. Adhi } \\
\text { Karya }\end{array}$ & $\begin{array}{l}\text { Besi Beton } \\
\text { Besi Baja } \\
\text { Besi IWF } \\
\text { Besi Siku } \\
\text { Besi CNP }\end{array}$ & Tidak Ada & $\begin{array}{l}\text { Cash dan } \\
\text { SCF }\end{array}$ & $\begin{array}{l}\text { Tidak } \\
\text { Ada }\end{array}$ & $\begin{array}{l}\text { Pembayaran ada } \\
2 \text { tipe, pertama } \\
\text { untuk <100 juta } \\
\text { pembayaran } \\
\text { secara langsung. } \\
\text { Sedangkan untuk } \\
>100 \text { juta } \\
\text { pembayaran } \\
\text { dengan sistem } \\
\text { SCF. } \\
\text { Pembayaran } \\
\text { barang setelah } \\
\text { barang sampai } \\
\text { ditempat dan } \\
\text { dimulai } 1 \\
\text { minggu setelah } \\
\text { tagihan diterima. } \\
\text { Barang bersifat } \\
\text { ready stock. } \\
\text { Telah memiliki } \\
\text { hubungan baik } \\
\text { sejak lama. } \\
\text { Masalah yang } \\
\text { terjadi yaitu } \\
\text { keterlambatan }\end{array}$ \\
\hline
\end{tabular}




\begin{tabular}{|c|c|c|c|c|c|c|}
\hline & & & & & & pembayaran. \\
\hline $\begin{array}{l}\text { PT. Ayu } \\
\text { Kembang } \\
\text { Karya }\end{array}$ & $\begin{array}{l}\text { PT. Adhi } \\
\text { Karya }\end{array}$ & $\begin{array}{l}\text { Escavator } \\
\text { Bulldozer } \\
\text { Vibrator }\end{array}$ & Tidak Ada & $\begin{array}{l}\text { Per } 200 \text { jam } \\
\text { pemakaian }\end{array}$ & $\begin{array}{l}\text { Tidak } \\
\text { Ada }\end{array}$ & $\begin{array}{l}\text { Pembayaran } \\
\text { dilakukan secara } \\
\text { Cash setelah } 200 \\
\text { jam pemakaian. } \\
\text { Peralatan yang } \\
\text { digunakan hanya } \\
\text { yang tersedia } \\
\text { (Ready Stock). } \\
\text { Hambatan yang } \\
\text { terjadi yaitu } \\
\text { keterlambatan } \\
\text { pembayaran. } \\
\text { Tidak ada kotrak } \\
\text { yang digunakan, } \\
\text { kerjasama hanya } \\
\text { berdasarkan } \\
\text { kepercayaan dan } \\
\text { hubungan baik }\end{array}$ \\
\hline
\end{tabular}

\subsection{Faktor Penentu Kelancaran Kerjasama Pada Proyek Jembatan}

\section{a. Kepercayaan}

Dengan adanya kepercayaan antara kedua belah pihak akan menimbulkan hubungan yang baik sehingga jika terjadi konflik ketika pendistribusian maupun keterlambatan pembayaran tidak akan menimbulkan kecurigaan antara kedua belah pihak yang berinteraksi.

\section{b. Komunikasi}

Faktor komunikasi yang baik antara kontraktor utama dengan subkontraktor maupun supplier akan mempermudah dalam pelaksanaan pekerjaan dan pengadaan material dan peralatan yang dibutuhkan oleh konraktor.

\section{c. Kualitas}

Menjaga kualitas sama dengan menjaga hubungan baik antar perusahaan. Dengan jaminan kualitas yang baik dari pemasok, subkontraktor dan kontraktor utama maka pekerjaan kontruksi dapat dilaksanakan dengan baik. Kualitas berpengaruh dalam kelancaran proyek. Dengan demikian, jika suatu perusahaan dapat menjaga kualitasnya sesuai dengan spesifikasi teknis yang disyaratkan oleh owner, maka peluang untuk ikut serta kembali pada proyek berikutnya lebih besar.

\section{d. Waktu}

Kemampuan untuk memanage waktu dengan baik merupakan sebuah keharusan. Dengan hal ini, secara tidak langsung penyedia dapat memperoleh keuntungan lebih. Maka dari itu, ketepatan waktu menjadi bagian yang sangat penting dalam kelancaran suatu proyek. Ketepatan waktu ini sangat dipengaruhi oleh kepercayaan, kualitas, dan komunikasi.

\section{KESIMPULAN DAN SARAN}

\subsection{Kesimpulan}

Dari penelitian yang telah dilakukan proyek kontruksi jembatan kelok 9 dapat disimpulkan yaitu:

1. Dari analisa terhadap rantai pasok proyek tersebut, didapati 4 pekerjaan yang dilakukan langsung oleh kontraktor yaitu pekerjaan drainase, pekerjaan tanah, pekerjaan perkerasan beton 
semen, dan pekerjaans ruktur. Dan 2 pekerjaaan yang dilakukan oleh subkontraktor yaitu pekerjaan aspal, dan pekerjaan minor. Sedangkan peralatan merupakan peralatan sewa.

2. Pada analisa rantai pasok juga didapatkan jumlah tier pada proyek kontruksi jembatan tersebut yaitu sampai pada tier 4 .

3. Dari analisa terhadap hubungan interaksi antara kontraktor dengan subkontraktor atau supplier pada proyek konstruksi tersebut didapatkan hasil yaitu faktor penentu kelancaran kerjasama pada proyek jembatanantara lain :

a. Kepercayaan yang baik.

b. Komunikasi yang lancar antara kontraktor utama dengan subkontrakto atau supplier.

c. Kualitas yang sesuai dengan spesifikasi yang telah ditetapkan.

d. Ketepatan waktu dalam penjadwalan dan pendistribusian.

\subsection{Saran}

1. Dapat mencari referensi sebanyak mungkin yang lebih mendukung penelitian.

2. Membandingkan struktur rantai pasok jembatan ini dengan proyek jembatan lain dengan kontraktor dan lokasi yang berbeda.

\section{DAFTAR KEPUSTAKAAN}

Suradji, Akhmad. Ir. (2006), Diktat Kuliah Manajemen Konstruksi, Universitas Andalas. padang.

Indrajit, Richardus Eko, Djokopranoto. (2003), Konsep Manajemen Supply Chain :Strategi Mengelola Manajemen Rantai Pasokan Bagi Perusahaan Modern di Indonesia, PT Gramedia Widiasarana Indonesia. Jakarta

1994, Kamus Besar Bahasa Indonesia, Balai Pustaka. Jakarta.

.2004,Oxford Dictionary of Biografi Nasional, Oxford University Press.Inggris

Keraf, Gorys. (1995), Komposisi Lanjutan II, Grasindo. Jakarta.

Russell RS, Taylor BW. (2000), Operation Management: Multimedia Version, The Prentice Hall Inc.New Jersey.

Chopra, Sunil Meindl, Peter. (2004), Supply Chain Management, Pearson Education.New Jersey.

London, Kerry. (2004), Construction Supply Chain Procurement Modelling, The University of Melbourne : Printed on acid-free paper. Melbourne

Dirohanta, Rona. (2012), Struktur Rantai Pasok Pada Proyek Konstruksi, Universitas Andalas. Padang.

Suraji, Akhmad dan Rona Dirohanta. (2012), Rantai Pasok Konstruksi Di Sektor Gedung, Universitas Andalas. Padang.

Yasin, Nazarkhan. (2006), Mengenal Kontrak Kontruksi di Indonesia, PT. Gramedia Pustaka Utama. Jakarta 